\title{
Photosynthesis, carbon uptake and antioxidant defence in two coexisting filamentous green algae under different stress conditions
}

\author{
K. S. Choo ${ }^{1}$, J. Nilsson ${ }^{2}$, M. Pedersén ${ }^{1}$, P. Snoeijs ${ }^{2, *}$ \\ ${ }^{1}$ Department of Botany, Stockholm University, Lilla Frescativägen 5, 10691 Stockholm, Sweden \\ ${ }^{2}$ Department of Ecology and Evolution, Evolutionary Biology Centre, Uppsala University, Villavägen 14, 752 36 Uppsala, Sweden
}

\begin{abstract}
The physiological basis for ecological processes is in many cases little understood. The purpose of this work was to link 3 important physiological processes in algae - photosynthesis, carbon uptake and antioxidant defence - to life form. The organisms used were the morphologically similar filamentous green algal species Cladophora glomerata and Ulva procera, which seemingly occupy the same niche when they co-occur in dense belts in the upper littoral zone of the brackish Baltic Sea in summer. Their life strategies are different: the annual C. glomerata usually stays attached throughout summer, while the ephemeral $U$. procera can appear and disappear from the same site from week to week. The algae were growing in the field under exactly the same conditions (mixed stands) and were immediately used in experiments at a field station. Fundamental ecophysiological differences were found between the 2 species. (1) Higher photosynthetic activity was detected in U. procera. (2) More shade-adaptations were found in U. procera, and more sun-adaptations in C. glomerata. (3) C. glomerata uses a proton pump for $\mathrm{HCO}_{3}{ }^{-}$transport, and carbon uptake does not depend on periplasmic carbonic anhydrase. This is an advantage in dense algal belts with longer periods of carbon limitation. (4) C. glomerata invests more in carotenoid protection against oxidative stress, including high carotenoid/chlorophyll ratios and a functional violaxanthin xanthophyll cycle. (5) U. procera was more sensitive to oxidative stress created by UV-B radiation than C. glomerata, which correlates with a more effective intracellular (carotenoid and enzymatic) defence against oxidative stress in C. glomerata. (6) $\mathrm{H}_{2} \mathrm{O}_{2}$ in the seawater medium had a negative effect on photosynthesis in C. glomerata, but not in U. procera. This suggests that a high release of $\mathrm{H}_{2} \mathrm{O}_{2}$ by $U$. procera under oxidative stress may damage C. glomerata. While the ecophysiological traits of C. glomerata seem to be directed toward persistence, those of $U$. procera seem to be more engaged with large but short-term gains. This is in accordance with their different life strategies.
\end{abstract}

KEY WORDS: Macroalgae · Ecophysiology · Photosynthesis · Carbon uptake · Oxidative stress · Xanthophyll cycle $\cdot$ Pigments $\cdot$ Baltic Sea

- Resale or republication not permitted without written consent of the publisher

\section{INTRODUCTION}

Strong correlations occur between macroalgal morphologies, life strategies, ecophysiological traits and the environment in which they live. Macroalgal thallus morphology and photosynthetic rates are closely linked, with thin filamentous r-strategists having the highest rates per unit weight (Littler \& Littler 1980, Weykam et al. 1996, Johansson \& Snoeijs 2002). Patterns of disparate spatial occurrence are often related to ecophysiological traits. For example, algal depth zonations show gradients in compensation irradiances of species, with deeper growing algae being more sensitive to light, while UV-tolerant algae grow closer to the surface (Bischof et al. 1998, Johansson \& Snoeijs 2002, Figueroa et al. 2003). Similarly, depth distribution and the possession of certain carbonuptake mechanisms seem to be related to deeper growing red algae being unable to take up $\mathrm{HCO}_{3}{ }^{-}$ (Maberly 1990), whereas algae in the upper littoral 
have flexible $\mathrm{HCO}_{3}{ }^{-}$utilisation systems (Axelsson et al. 1995). The hypothesis of the competitive exclusion principle postulates that species with the same requirements cannot live together in the same place (Stiling 2002). However, nature is full of coexisting and competing species with strongly overlapping requirements. In algal belts complicated ecological interactions involving dispersal mechanisms, herbivory and seasonality can partly explain patterns of coexistence (Lotze et al. 2000). However, it may also be possible that ecophysiological traits are coupled to patterns of spatial co-occurrence. We hypothesised that cooccurring species with very similar morphologies differ in life strategies as well as in ecophysiological traits and that these strategies and traits are correlated.

An excellent example of the co-occurrence of algae with similar morphologies is that of Cladophora glomerata (L.) Kütz. and Ulva procera (Ahlner) Hayden et al. (= Enteromorpha procera Ahlner = Enteromorpha ahlneriana Bliding, see Hayden et al. 2003). C. glomerata is of freshwater origin and $U$. procera is of marine origin, but in the brackish Baltic Sea they co-exist (Snoeijs 1999). Together these 2 filamentous green algae dominate the upper metre of the littoral zone of the northern Baltic Sea during summer. This zone is known as the 'Cladophora-belt', but, in fact, it consists of the 2 species mentioned and low abundances of some other filamentous algae. This belt is an important habitat for many invertebrates. Macroscopically, C. glomerata and $U$. procera are difficult to distinguish from each other because they have the same finely branched filamentous morphology, the same colour and the same size (10 to $30 \mathrm{~cm}$ high). Microscopically, they differ in that $C$. glomerata has larger uniseriate cells, while the cells of $U$. procera are smaller and arranged in 1-cell-layer thick tubes. C. glomerata and $U$. procera are found in single-species belts, but very often also in patches in mixed stands (Snoeijs 1992, 1999). C. glomerata is slightly more abundant than $U$. procera; at 20 sampling sites visited monthly from March to November, C. glomerata occurred on $86 \%$ and $U$. procera on $71 \%$ of 180 sampling occasions (Snoeijs 1992). The upper littoral of the Baltic Sea is a highly dynamic environment; lunar tides are virtually absent, but daily changes in the water level of up to ca. $0.5 \mathrm{~m}$ may occur, together with changes in temperature and irradiance. In this habitat, the annual $C$. glomerata usually stays attached throughout summer, while the ephemeral $U$. procera can appear and disappear at the same site from week to week.

Previous studies on cellular defence strategies against oxidative stress by Choo et al. (2004) showed that Cladophora glomerata can be classified as a more stress-tolerant species and Ulva procera as a more stress-susceptible species. Low temperature in combi- nation with high irradiance created less lipid oxidative damage in C. glomerata than in U. procera, which was correlated to higher regular activities of the $\mathrm{H}_{2} \mathrm{O}_{2}$ scavenging enzymes catalase and ascorbate peroxidase in C. glomerata cells. Higher activities of these enzymes in $U$. procera were only mobilised after the introduction of oxidative stress. Superoxide dismutase activities were similar in both species, but the mechanisms to remove the $\mathrm{H}_{2} \mathrm{O}_{2}$ produced by the action of this enzyme were different: more through scavenging enzymes inside C. glomerata cells and more through diffusion into the seawater medium for $U$. procera. In the present paper, we make further comparisons on antioxidant defence by carotenoids against high photosynthetically active radiation (PAR) and sensitivity to ultraviolet-B (UV-B) radiation (creating oxidative stress) of the 2 species. As both species occur in the upper littoral zone, it would be expected that they are well protected against supersaturating PAR and UV-B radiation, which can damage components of metabolic processes in algal cells and lower the photosynthetic capacity (Lorenz et al. 1997, Bischof et al. 2002, Figueroa et al. 2003).

In 2 previous papers (Abrahamsson et al. 2003, Choo et al. 2004) we compared the releases of $\mathrm{H}_{2} \mathrm{O}_{2}$ into the seawater medium by Cladophora glomerata and Ulva procera sampled from the same sites in the Baltic Sea and incubated under the same stress conditions in the laboratory (high irradiance and carbon deficiency). C. glomerata and $U$. procera from Forsmark, in the southern Bothnian Sea, released up to 2.2 and $49 \mu \mathrm{mol}$ $\mathrm{H}_{2} \mathrm{O}_{2}$ (g DW) $)^{-1} \mathrm{~h}^{-1}$, respectively. C. glomerata and U. procera from Askö, in the northern Baltic Sea proper, released up to 1.3 and $6.0 \mu \mathrm{mol} \mathrm{H}_{2} \mathrm{O}_{2}(\mathrm{~g} \mathrm{DW})^{-1} \mathrm{~h}^{-1}$, respectively. We speculated that the release of $\mathrm{H}_{2} \mathrm{O}_{2}$ may function as a chemical defence against herbivores and epiphytes or as an allelochemical in direct competition with other algal species. For Ulva rigida C. Ag., Collén \& Pedersén (1996) found that photosynthesis and carbon uptake were inhibited at a concentration of $1000 \mu \mathrm{M}$ $\mathrm{H}_{2} \mathrm{O}_{2}$ in seawater, but not at concentrations as high as $100 \mu \mathrm{M}$. They concluded that the release of $\mathrm{H}_{2} \mathrm{O}_{2}$ by $U$. rigida of up to $1.2 \mu \mathrm{mol} \mathrm{H}_{2} \mathrm{O}_{2}$ (g fresh weight) ${ }^{-1} \mathrm{~h}^{-1}$ (Collén et al. 1995), which is about $12 \mu \mathrm{mol} \mathrm{H}_{2} \mathrm{O}_{2}$ (g $\mathrm{DW})^{-1} \mathrm{~h}^{-1}$, had no direct autotoxic effect. In the present study, we test whether there are differences in sensitivity to extracellular $\mathrm{H}_{2} \mathrm{O}_{2}$ between C. glomerata and $U$. procera, in support of a possible role of $\mathrm{H}_{2} \mathrm{O}_{2}$ in interspecific competition between these 2 species.

In the light of their coexistence and similar morphologies, but different life strategies and different defences against oxidative stress, we investigate here the hypothesis that the annual Cladophora glomerata and the ephemeral Ulva procera exhibit differences in the fundamental cellular processes of photosynthesis 
and carbon uptake. We also study carotenoid responses to high irradiance and photosynthetic responses to $\mathrm{H}_{2} \mathrm{O}_{2}$ and UV-B radiation for a further comparison of the 2 species' ecophysiological traits with respect to their life strategies. To be able to relate the results to field conditions, the algae were not transported or cultivated, but were taken directly in the field, $20 \mathrm{~m}$ from the field station where all experiments were carried out. Our study does not include seasonal variation and only reflects summer conditions, when the Cladophora-belt in the Baltic Sea has already been established and is at its highest state of development.

\section{MATERIALS AND METHODS}

Cladophora glomerata and Ulva procera were collected from a mixed stand at a water depth of 0.2 to $0.3 \mathrm{~m}$ on the island of Askö, in the northern Baltic Sea proper $\left(58^{\circ} 50^{\prime} \mathrm{N}, 17^{\circ} 39^{\prime} \mathrm{E}\right)$. All algae were growing on a concrete ridge at a $45^{\circ}$ angle to the water surface, so that the microhabitat was as uniform as possible. Fresh algal samples were collected, rinsed several times with filtered seawater to remove epiphytes and preincubated in the darkness at $25^{\circ} \mathrm{C}$ for at least $2 \mathrm{~h}$, to avoid acclimation to different irradiances in the field before use in the experiments. Algae sampled from 24 July to 2 August 2002 were used for measurements of photosynthesis, carbon uptake and pigment dynamics. Sensitivity to UV-B radiation and sensitivity to the carbon-uptake inhibitor acetazolamide were studied on 30 and 31 August 2000 in algae taken at the same site and sampled in the same way as in 2002. In both years, salinity was 6.5 practical salinity units (psu) and water temperature in the upper littoral was 20 to $25^{\circ} \mathrm{C}$ during sampling.

Measurements of photosynthetic rates $\left(\mathrm{O}_{2}\right.$ evolution) were carried out with 2 intercalibrated computersteered Illuminova Light Dispenser Systems ('Light Pipette'); each was equipped with a halogen lamp, a patented IR deflector and a waveband definer delimiting radiation between 400 and $700 \mathrm{~nm}$. One of the advantages of the Light Pipette is its great illumination precision. Illumination was calibrated with a Li-Cor radiometer, with a cosine-corrected sensor inserted in the Light Pipette exactly at the site of incubation of the algae. During the experiments, irradiance was measured by a light sensor positioned immediately next to the incubation chamber of the Light Pipette at the same distance from the PAR and UV light sources as the incubated algae. The percent $\mathrm{O}_{2}$ saturation and change in the percent $\mathrm{O}_{2}$ saturation (photosynthetic rate) were recorded every $2 \mathrm{~s}$. In all experiments pieces of Cladophora glomerata or Ulva procera of 0.03 to $0.04 \mathrm{~g}$ fresh weight were incubated in nutrient-enriched, filtered
$(0.2 \mu \mathrm{m})$ natural seawater (NSW) with an air-calibrated $\mathrm{O}_{2}$ concentration in a $2.6 \mathrm{ml}$ incubation chamber with an $\mathrm{O}_{2}$ electrode (Microelectrodes) inserted. Since the NSW at the sampling site is low in nutrients in July (mean \pm SD for 8, 14 and 19 July 2000: $0.29 \pm 0.26 \mu \mathrm{M}$ dissolved inorganic $\mathrm{N}$ and $0.14 \pm 0.06 \mu \mathrm{M}$ dissolved inorganic $\mathrm{P}_{i}$ I. Wänstrand \& P. Snoeijs unpubl. data), $6.4 \mu \mathrm{M}$ of $\mathrm{NaNO}_{3}$ and $0.4 \mu \mathrm{M}$ of $\mathrm{NaH}_{2} \mathrm{PO}_{4}$ (approximate winter concentrations in the area) were added to the filtered NSW to avoid nutrient limitation during the experiments. All experiments were carried out at $25^{\circ} \mathrm{C}$. For each treatment, 3 to 5 replicate measurements were carried out, each on a different algal specimen. Replicate experiments were performed at different times of the day to minimise possible diel effects. Photosynthetic rates were normalised to algal dry weight (DW) measured after $24 \mathrm{~h}$ of oven-drying at $80^{\circ} \mathrm{C}$ and to chlorophyll a (chl a). Separate samples were taken for the analyses of total $\mathrm{C}, \mathrm{N}$ and $\mathrm{P}$ in the algal thalli with a LECO CHNS-932 elemental analyser.

Photosynthetic properties were studied by constructing photosynthesis versus irradiance curves ( $P$ - $E$ curves). A $1200 \mathrm{~s}$ programme was run, starting with $120 \mathrm{~s}$ in the darkness followed by 18 alternating light and dark periods of $60 \mathrm{~s}$ each. The photon flux density was increased for each of the 9 light periods and measured 10, 20, 50, 100, 300, 600, 900, 1500 and $2000 \mu \mathrm{mol}$ photons $\mathrm{m}^{-2} \mathrm{~s}^{-1}$, respectively. Data used to construct $P$ - $E$ curves were the means of the last 20 of a total of $30 \mathrm{O}_{2}$ records in each time period; this allowed for a $20 \mathrm{~s}$ lag phase for differences in gas exchange between species due to thallus thickness. The curves were fitted using the equation: $P_{\text {net }}$ $=\left[\mathrm{P}_{\max } \times \tanh \left(\alpha \times E / \mathrm{P}_{\max }\right)\right]+R_{\mathrm{d}}$ (Jassby \& Platt 1976, Henley 1993), employing the Levenberg-Marquardt algorithm for the parameter estimates $\mathrm{P}_{\max }$ and $\alpha\left(P_{\text {net }}=\right.$ net rate of photosynthesis, $\mathrm{P}_{\max }=$ light-saturated photosynthetic rate, $\alpha=$ initial slope at limiting irradiance levels, $E=$ irradiance, $R_{\mathrm{d}}=$ rate of respiration in darkness). The derived measures $E_{\mathrm{C}}=-R_{\mathrm{d}} / \alpha$ (compensation irradiance) and $E_{\mathrm{k}}=\mathrm{P}_{\max } / \alpha$ (saturation irradiance) were calculated.

In the study on pigment dynamics each Light Pipette measurement consisted of a 1200 s programme including $600 \mathrm{~s}$ of darkness followed by $600 \mathrm{~s}$ of irradiance. Ten different irradiance levels $(0,10,20,50,100,300$, $600,900,1500$ and $2000 \mu \mathrm{mol}$ photons $\mathrm{m}^{-2} \mathrm{~s}^{-1}$ ) were used. Data used in the calculations were the last $360 \mathrm{~s}$ in each dark or light period, which allowed for a $240 \mathrm{~s}$ acclimation phase to light conditions. After incubation, the algae were transferred within $10 \mathrm{~s}$ to a freezer set to $-86^{\circ} \mathrm{C}$. Later, chlorophylls and carotenoids were extracted and analysed by high-performance liquid chromatography (HPLC) according to Ursi et al. (2003).

The sensitivity of Cladophora glomerata and Ulva procera to $\mathrm{H}_{2} \mathrm{O}_{2}$ in the NSW medium was measured as changes in $P$-E curves after the addition of 20 and 
$100 \mu \mathrm{M} \mathrm{H}_{2} \mathrm{O}_{2}$ to the NSW. A method using luminoldependent chemiluminescence (LDC) was used to determine the concentrations of $\mathrm{H}_{2} \mathrm{O}_{2}$ in the seawater medium (modified after Glazener et al. 1991). A $5 \mathrm{mM}$ luminol (5-amino-2,3-dihydro-1,4-phtalazinedone) solution of pH 7.6 was prepared in $1 \mathrm{ml}$ of $1 \mathrm{M} \mathrm{NaOH}$ and $9 \mathrm{ml}$ of $0.4 \mathrm{M}$ Mops (3-N-morpholino propane sulfonic acid, $\mathrm{pH}$ 7.0). A horseradish peroxidase solution was prepared in $0.1 \mathrm{M}$ phosphate buffer ( $\mathrm{pH} 7.0$ ) with an enzyme activity of $28 \mathrm{U} \mathrm{ml}^{-1}$. Then, $16 \mu \mathrm{l}$ luminol solution and $48 \mu \mathrm{l}$ peroxidase solution were mixed, and $1 \mathrm{ml}$ seawater was added. LDC was measured with a luminometer (LKB 1250, Wallac) equipped with a flat-bed recorder (Kipp \& Zonen). A standard curve was prepared based on solutions with different concentrations of $\mathrm{H}_{2} \mathrm{O}_{2}$.

To study the effect of a strong external source of oxidative stress, the algae were exposed to UV-B radiation. An UV lamp providing $1.58 \mathrm{~W} \mathrm{~m}^{-2} \mathrm{UV}-\mathrm{A}$ (315 to $400 \mathrm{~nm}$ ) and $2.45 \mathrm{~W} \mathrm{~m}^{-2} \mathrm{UV}-\mathrm{B}$ (280 to $315 \mathrm{~nm}$ ), i.e. close to natural levels for UV-B at the water surface, but only ca. $4 \%$ of natural UV-A levels (Dring et al. 1996), was inserted into a special construction in front of the incubation chamber of the Light Pipette. Then, 5 successive Light Pipette runs were made with the same thallus at a constant irradiance of $300 \mu \mathrm{mol}$ photons $\mathrm{m}^{-2} \mathrm{~s}^{-1}$. This experiment was carried out for Cladophora glomerata and Ulva procera, and for comparison also with another Ulva species, U. intestinalis L., which is common in the Baltic Sea. Each run consisted of a $600 \mathrm{~s}$ long programme, and the seawater medium was exchanged between the runs to keep $\mathrm{O}_{2}$ saturation $<130 \%$ and to avoid carbon limitation. The first run without UV-B radiation acted as the control, Runs 2 to 4 included UV-B radiation. The fifth run without UV-B radiation was a postcontrol to record the degree of $\mathrm{O}_{2}$ evolution recovery. Reference experiments consisting of 5 successive runs without UV-B radiation were performed as well. The UV-B effect was expressed as the $\mathrm{O}_{2}$ evolution as percent of the control.

The occurrence of different carbon-uptake mechanisms in the 2 species was studied by a pH-drift technique in which photosynthetic carbon uptake was followed by $\mathrm{pH}$ increase in the seawater medium, as previously described in detail by Choo et al. (2002), Snoeijs et al. (2002) and Ray et al. (2003). The pH was recorded every minute for $7 \mathrm{~h}$ in nutrient-enriched, filtered NSW during photosynthesis of Cladophora glomerata and Ulva procera in closed glass flasks with $\mathrm{pH}$ electrodes inserted in a computerised set-up, with and without the addition of inhibitors for specific carbon-uptake mechanisms. Each experiment was carried out on 2 consecutive days using the same algal thalli. The first day consisted of a $7 \mathrm{~h}$ run without inhibitor to activate and stabilise the algae (Choo et al. 2002), and the second day consisted of a $7 \mathrm{~h}$ run with or without inhibitor. The data presented are only those of the second day. During the experiments, the temperature was kept at 25 to $26^{\circ} \mathrm{C}$ by air-fans. Light was supplied at $300 \mu \mathrm{mol}$ photons $\mathrm{m}^{-2} \mathrm{~s}^{-1}$ by 4 daylight fluorescent tubes placed on both sides of the flasks. Acetazolamide (AZ, Sigma), an inhibitor of periplasmic carbonic anhydrase (CA) (Moroney et al. 1985, Björk et al. 1992), was prepared as a $50 \mathrm{mM}$ stock solution in $0.5 \mathrm{M} \mathrm{NaOH}$. A final concentration of $0.2 \mathrm{mM}$ AZ was added to the seawater medium in the experiments. A $20 \mathrm{mM}$ stock solution of 4,4'-diisothiocyanato-stilbene 2,2'-disulfonic acid (DIDS, Sigma), which inhibits the action of an anion exchange protein (AE; Drechsler et al. 1993), was prepared in distilled water. A final concentration of $0.3 \mathrm{mM}$ DIDS was added to the seawater medium in the experiments. Orthovanadate (VAN, Sigma), an inhibitor of P-type $\mathrm{H}^{+}$-ATPases (proton pump; Gilmour et al. 1985), was prepared as a $50 \mathrm{mM}$ stock solution in distilled water and added to the seawater medium in a final concentration of $0.15 \mathrm{mM}$.

Sensitivity of photosynthesis to AZ was studied by performing 3 successive Light Pipette runs with the same thallus at a constant irradiation of $300 \mu \mathrm{mol}$ photons $\mathrm{m}^{-2} \mathrm{~s}^{-1}$. Each run consisted of a $600 \mathrm{~s}$ long sequence, with $\mathrm{O}_{2}$ recordings every second. The seawater medium was exchanged between the runs to keep $\mathrm{O}_{2}$ saturation $<130 \%$ and to avoid carbon limitation. The first run without AZ acted as a control; in the second run, $0.2 \mathrm{mM} \mathrm{AZ}$ was added to the seawater medium; the third run, without AZ, was a postcontrol to show that it was possible to wash away AZ. The AZ effect was expressed as the $\mathrm{O}_{2}$ evolution in percent of the control. Reference experiments consisting of 3 successive runs without AZ radiation were performed as well.

For statistical data elaboration ( $t$-test and repeatedmeasures ANOVA) STATISTICA software was used. Significance was accepted at $\mathrm{p}<0.05$.

\section{RESULTS}

\section{Morphology and nutrient contents}

The tube-like thallus of Ulva procera was very thin and similar to the uniseriate thallus of Cladophora glomerata. At the sampling site, the richly branched tufts of both species were ca. $20 \mathrm{~cm}$ high and it was difficult to distinguish the 2 species in situ; the only macroscopic difference was the slightly darker green colour of U. procera. Epiphyte cover was low on both species. The DW/WW ratio, \% $\mathrm{C}$ and $\% \mathrm{~N}$ of $C$. glomerata and $U$. procera did not differ significantly between the species (Table 1). The \% $\mathrm{P}$ was significantly lower in $U$. procera $(0.14 \%)$ than in C. glomerata $(0.26 \%)$, and, consequently, the N/P ratio was higher in $U$. procera. 
Table 1. Cladophora glomerata and Ulva procera. Comparisons of the nutrient contents and ratios of the thalli used in the experiments, given as overall mean $\pm \mathrm{SD}(\mathrm{n}=4 \mathrm{~d})$ based on daily means of 3 replicate algal thalli measured on $25,27,29$ and 31 July. $t$-tests were performed to test for differences in the means of the 2 species. DW: dry weight; WW: wet weight

\begin{tabular}{|lrrr|}
\hline Property & $\begin{array}{c}t \text {-test } \\
\text { p-value }\end{array}$ & C. glomerata & U. procera \\
\hline DW/WW & 0.347 & $0.12 \pm 0.02$ & $0.11 \pm 0.02$ \\
$\% \mathrm{C}$ & 0.166 & $31.05 \pm 2.20$ & $33.20 \pm 1.60$ \\
$\% \mathrm{~N}$ & 0.737 & $2.09 \pm 0.60$ & $1.96 \pm 0.39$ \\
$\% \mathrm{P}$ & 0.001 & $0.26 \pm 0.03$ & $0.14 \pm 0.03$ \\
$\mathrm{C} / \mathrm{N}$ & & & \\
(on a molar basis) & 0.524 & $18.4 \pm 4.4$ & $20.4 \pm 3.7$ \\
N/P & & & \\
(on a molar basis) & 0.017 & $17.8 \pm 3.1$ & $32.0 \pm 8.1$ \\
\hline
\end{tabular}

\section{$P-E$ curves}

Ulva procera had higher weight-specific $\mathrm{P}_{\max }$ and $\alpha$ values, indicating a higher efficiency of photosynthesis in $U$. procera (Table 2). Also chl a-specific $\alpha$ was higher in $U$. procera, but chl a-specific $\mathrm{P}_{\max }$ was not significantly different in the 2 species. The coefficients of variance (CV) for $\mathrm{P}_{\max }$ and $\alpha$ showed larger variation between days in $U$. procera $(\mathrm{CV}=27$ and $23 \%$, respectively than

Table 2. Cladophora glomerata and Ulva procera. Comparisons of the photosynthetic properties extracted from $P-E$ curves for algae taken directly from the field on 24 July, 31 July, 1 August and 2 August 2002. The properties are given as overall mean $\pm \mathrm{SD}(\mathrm{n}=4 \mathrm{~d})$, based on daily means of 3 to 5 replicate algal thalli measured on 4 different days. $\mathrm{P}_{\max }$ : light-saturated photosynthetic rate; $R_{\mathrm{d}}$ : respiration rate in darkness; $\alpha$ : initial slope of photosynthesis; $E_{\mathrm{c}}=-R_{\mathrm{d}} / \alpha$ (compensation irradiance); $E_{\mathrm{k}}=\mathrm{P}_{\max } / \alpha$ (saturation irradiance). $t$-tests were performed to test for differences in the means of the 2 species

\begin{tabular}{|c|c|c|c|}
\hline $\begin{array}{l}\text { Measured and calculated } \\
\text { photosynthetic properties }\end{array}$ & $\begin{array}{c}t \text {-test } \\
\mathrm{p} \text {-value }\end{array}$ & C. glomerata & U. procera \\
\hline $\begin{array}{l}\mathrm{P}_{\max } \\
\left(\mu \mathrm{mol} \mathrm{O} \mathrm{O}_{2}[\mathrm{~kg} \mathrm{DW}]^{-1} \mathrm{~s}^{-1}\right) \\
\left(\mu \mathrm{mol} \mathrm{O} \mathrm{O}_{2}[\mathrm{mg} \mathrm{chl} \mathrm{a}]^{-1} \mathrm{~h}^{-1}\right)\end{array}$ & $\begin{array}{l}0.007 \\
0.293\end{array}$ & $\begin{array}{c}69 \pm 6 \\
125 \pm 11\end{array}$ & $\begin{array}{l}157 \pm 43 \\
150 \pm 41\end{array}$ \\
\hline $\begin{array}{l}R_{\mathrm{d}} \\
\left(\mu \mathrm{mol} \mathrm{O}{ }_{2}[\mathrm{~kg} \mathrm{DW}]^{-1} \mathrm{~s}^{-1}\right) \\
\left(\mu \mathrm{mol} \mathrm{O} \mathrm{O}_{2}[\mathrm{mg} \mathrm{chl} \mathrm{a}]^{-1} \mathrm{~h}^{-1}\right)\end{array}$ & $\begin{array}{l}0.408 \\
0.012\end{array}$ & $\begin{array}{l}-19 \pm 6 \\
-34 \pm 10\end{array}$ & $\begin{array}{l}-16 \pm 3 \\
-15 \pm 3\end{array}$ \\
\hline 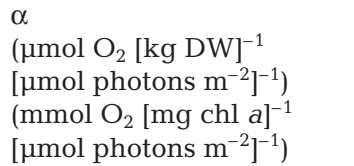 & 0.002 & $\begin{array}{l}0.39 \pm 0.02 \\
0.20 \pm 0.03\end{array}$ & $\begin{array}{l}1.09 \pm 0.25 \\
0.29 \pm 0.07\end{array}$ \\
\hline $\begin{array}{l}E_{\mathrm{c}} \\
\left(\mu \mathrm{mol} \text { photons } \mathrm{m}^{-2} \mathrm{~s}^{-1}\right) \\
E_{\mathrm{k}} \\
\left(\mu \mathrm{mol} \text { photons } \mathrm{m}^{-2} \mathrm{~s}^{-1}\right)\end{array}$ & 0.008 & $\begin{array}{r}50 \pm 18 \\
183 \pm 27\end{array}$ & $\begin{array}{c}15 \pm 5 \\
153 \pm 65\end{array}$ \\
\hline
\end{tabular}

in C. glomerata (CV $=9$ and $5 \%$, respectively). Chl aspecific $R_{\mathrm{d}}$ was higher in C. glomerata. The affinity for light of $U$. procera was higher than that of $C$. glomerata, as shown by its more than 3 time lower $E_{\mathrm{C}}$, while saturation irradiance $\left(E_{\mathrm{k}}\right)$ was similar for both species. The $P-E$ curves did not indicate chronic photoinhibition (manifested by $\mathrm{P}_{\max }$ decrease) at the studied irradiance levels of 0 to $2000 \mu \mathrm{mol}$ photons $\mathrm{m}^{-2} \mathrm{~s}^{-1}$.

\section{Carbon uptake}

All tested inhibitors significantly reduced the $\mathrm{pH}$ increase in the medium during photosynthesis in the pH-drift experiments (Fig. 1; tested by repeated-

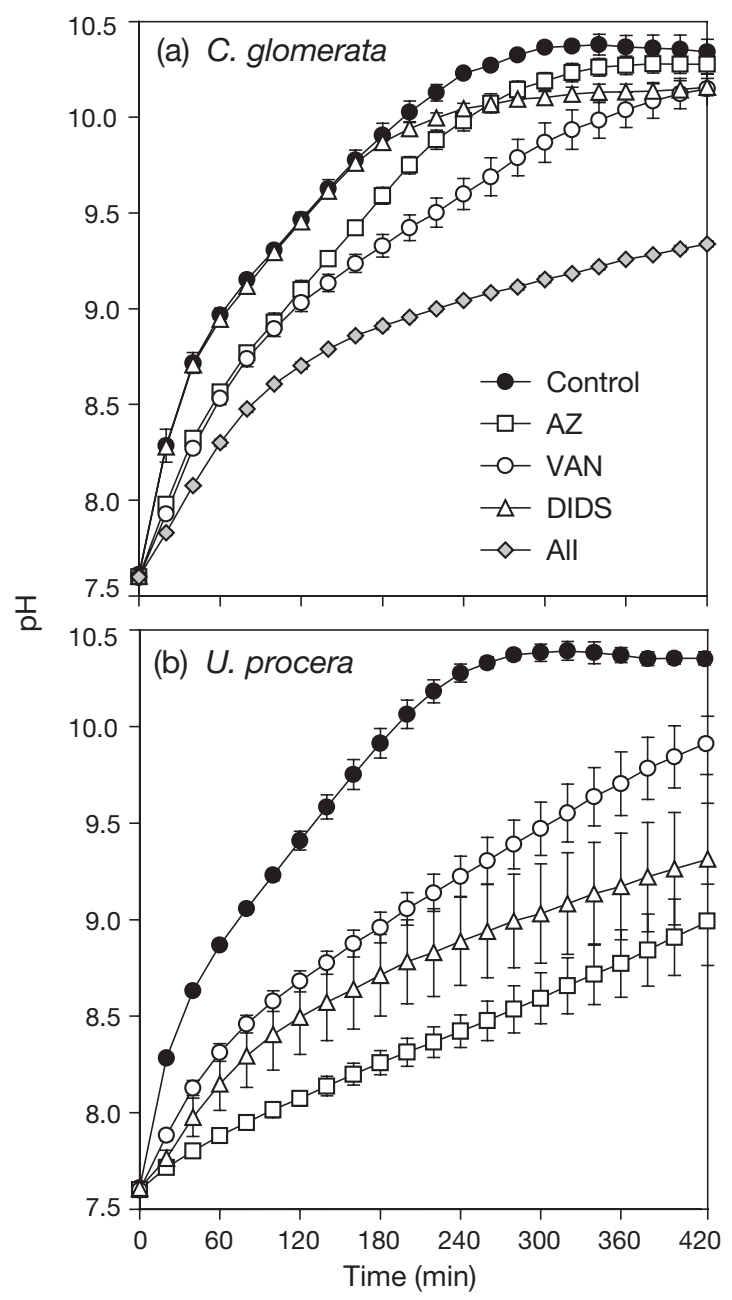

Fig. 1. Cladophora glomerata and Ulva procera. Changes in $\mathrm{pH}$ recorded in the seawater medium during $\mathrm{pH}$-drift experiments with (a) C. glomerata and (b) U. procera with different inhibitor treatments: control (without inhibitor), $0.2 \mathrm{mM}$ acetazolamide (AZ), $0.15 \mathrm{mM}$ vanadate (VAN) and $0.3 \mathrm{mM}$ 4, 4'-diisothiocyanato-stilbene-2,2'-disulfonic acid (DIDS). C. glomerata was also treated with all 3 inhibitors in combination (All). Error bars show 1 standard error of the mean (not visible when very small) 
measures ANOVA with time as the repeated-measures variable). The specific inhibitors AZ, VAN and DIDS identified the occurrence of 3 carbon-uptake mechanisms in both Cladophora glomerata and Ulva procera: an AZ-sensitive periplasmic CA, a VAN-sensitive P-type $\mathrm{H}^{+}$-ATPase (proton pump) and a DIDS-sensitive AE. In C. glomerata, the inhibitory effects of each of the inhibitors AZ, DIDS and VAN were small and inhibition by DIDS was only found at $\mathrm{pH}>9.8$. After $7 \mathrm{~h}$ there were no significant differences between the AZ treatment and the control (t-test, pH 10.28 to 10.34) or between the VAN and DIDS treatments (t-test, pH 10.15 to 10.16) (Fig. 1a). This suggests that within $7 \mathrm{~h}$ the proton pump and AE can compensate for the absence of periplasmic CA, but that CA cannot fully compensate for the absence of the proton pump or AE at high $\mathrm{pH}$. When all 3 inhibitors (AZ, VAN and DIDS) were used in combination in C. glomerata, a large inhibition of carbon uptake occurred. In U. procera, carbon uptake was highly dependent on periplasmic CA; when this enzyme was blocked, AE and the proton pump could not, or at least not within $7 \mathrm{~h}$, compensate for the loss in carbon uptake (Fig. 1b). Similarly, when AE was blocked, CA and the proton pump could not compensate for the loss in carbon uptake. Blocking the proton pump had the least effect on carbon uptake in $U$. procera; after $7 \mathrm{~h}$ the $\mathrm{pH}$ had risen to 9.9 in the VAN treatment. The effect of AZ on $\mathrm{O}_{2}$ evolution confirmed the $\mathrm{pH}$-drift results that CA is more important for carbon uptake in $U$. procera than in C. glomerata; $0.2 \mathrm{mM}$ AZ blocked $41 \pm 6 \%$ of the $\mathrm{O}_{2}$ evolution rate in $U$. procera compared with only $16 \pm 9 \%$ in C. glomerata.

\section{Pigment dynamics}

Ulva procera had higher chlorophyll and carotenoid concentrations per unit DW; however, per unit chl a carotenoid concentrations were almost 2 times higher in Cladophora glomerata (Table 3). During the pigment dynamics experiments, $\mathrm{O}_{2}$ production was higher in U. procera than in C. glomerata at irradiances above $E_{\mathrm{k}}$ (Fig. 2a,b). All pigment concentrations or ratios remained unchanged during the short-term (10 min) exposures to different irradiation levels varying from 0 to $2000 \mu \mathrm{mol}$ photons $\mathrm{m}^{-2} \mathrm{~s}^{-1}$ (ANOVA, $\left.\mathrm{p}>0.05\right)$, except for violaxanthin, antheraxanthin and zeaxanthin in C. glomerata. The sum of these 3 xanthophylls remained unchanged as well (Table 3), while they performed the interconversions typical of the xanthophyll cycle with increasing light, i.e. decreases in violaxanthin and antheraxanthin and an increase in zeaxanthin (Fig. 2c). U. procera also possessed these 3 xanthophylls, but in lower concentrations, and no xanthophyll cycling was detected (Fig. 2d).

\section{Sensitivity to $\mathrm{H}_{2} \mathrm{O}_{2}$}

The $\mathrm{H}_{2} \mathrm{O}_{2}$ additions significantly affected the $P-E$ curves of Cladophora glomerata negatively, but had no significant effect on the $P$-E curves of Ulva procera (Fig. 3; repeated-measures ANOVA). In 20 and $100 \mu \mathrm{M}$ $\mathrm{H}_{2} \mathrm{O}_{2}$, respectively, C. glomerata had a 9 and $25 \%$ lower $\mathrm{P}_{\max }, 23$ and $34 \%$ lower $\alpha, 79$ and $112 \%$ higher $R_{\mathrm{d}}$ and 125 and $231 \%$ higher $E_{\mathrm{c}}(t$-tests, $\mathrm{p}<0.05)$, but $E_{\mathrm{k}}$ was not affected. In $U$. procera, none of these photosynthetic parameters was affected by the $\mathrm{H}_{2} \mathrm{O}_{2}$ treatments ( $t$-tests, $\mathrm{p}>0.05$ ). The NSW had an initial $\mathrm{H}_{2} \mathrm{O}_{2}$ concentration of $0.28 \pm 0.05 \mu \mathrm{M}$; after the 15-min incubations without addition of $\mathrm{H}_{2} \mathrm{O}_{2}$, this had increased to $1.06 \pm 0.30 \mu \mathrm{M}$ for C. glomerata and to $0.44 \pm 0.14 \mu \mathrm{M}$ for $U$. procera. In the $20 \mu \mathrm{M} \mathrm{H}_{2} \mathrm{O}_{2}$ treatment, the concentrations decreased to $6.8 \pm 0.6 \mu \mathrm{M}$ for C. glomerata 
Fig. 2. Cladophora glomerata and Ulva procera. Results of the pigment dynamics experiments, showing $(a, b) \mathrm{O}_{2}$ evolution and (c,d) changes in the chl a-specific concentrations of the xanthophylls violaxanthin (Viola), antheraxanthin (Anthera) and zeaxanthin (Zea) in $(\mathrm{a}, \mathrm{c})$ C. glomerata and $(\mathrm{b}, \mathrm{d}) U$. procera. Error bars show 1 standard error of the mean (not visible when very small). PAR: photosynthetically active
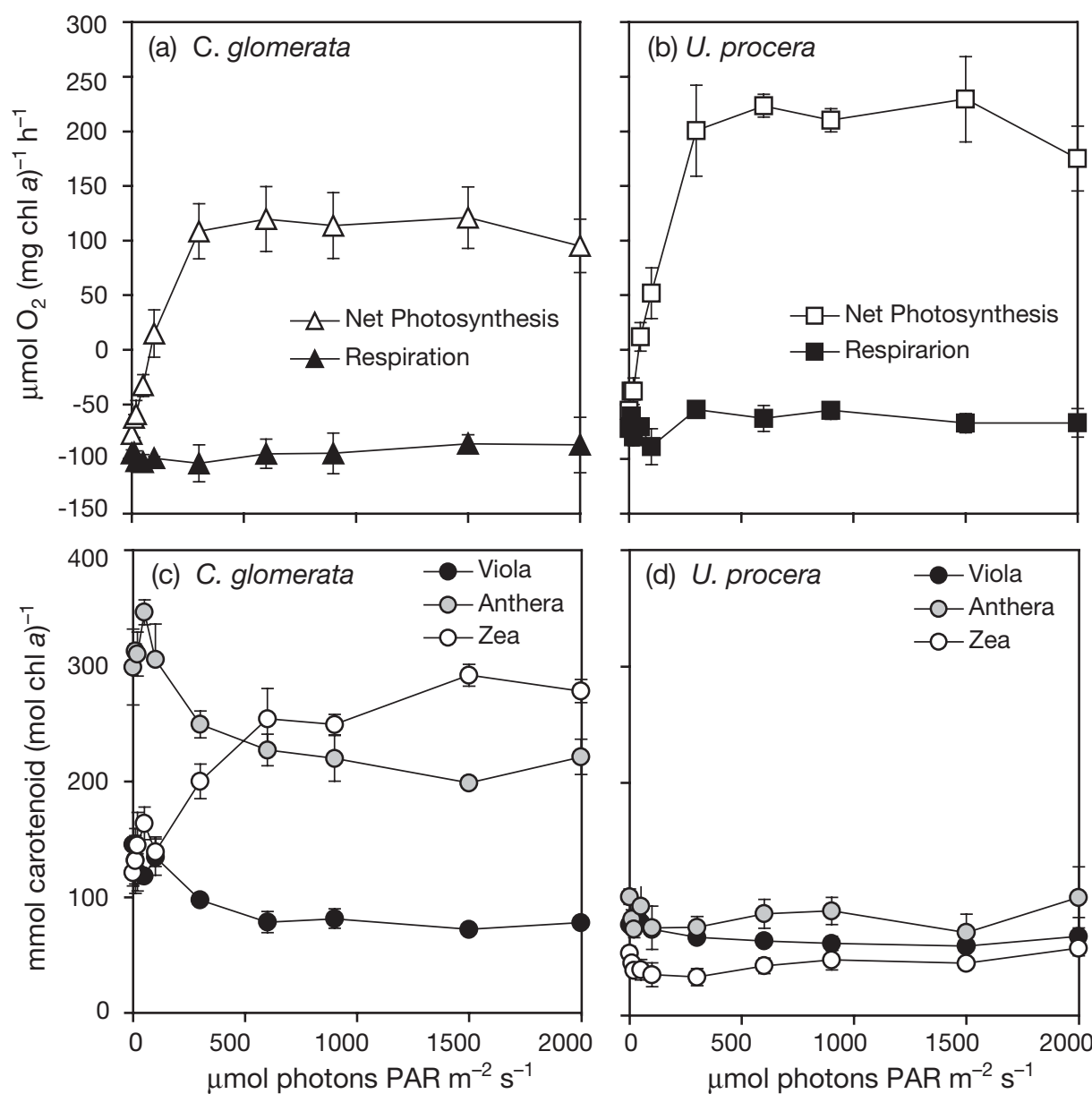

and to $6.0 \pm 0.6 \mu \mathrm{M}$ for $U$. procera. In the $100 \mu \mathrm{M} \mathrm{H}_{2} \mathrm{O}_{2}$ treatment, the concentrations decreased to $14.6 \pm 1.5$ $\mu \mathrm{M}$ for C. glomerata and to $15.7 \pm 0.5 \mu \mathrm{M}$ for $U$. procera. In control experiments without algae, the $\mathrm{H}_{2} \mathrm{O}_{2}$ concentrations decreased by ca. $50 \%$, probably by chemical degradation. These results show that photosynthesis in
C. glomerata was negatively affected by $\mathrm{H}_{2} \mathrm{O}_{2}$, but not in $U$. procera, and that both species were able to scavenge $\mathrm{H}_{2} \mathrm{O}_{2}$ added to the seawater. Maximum $\mathrm{H}_{2} \mathrm{O}_{2}$ levels in seawater taken within the dense algal belt at the sampling site varied between 1 and $15 \mu \mathrm{M}$ (measured on different days at noon).
Fig. 3. Cladophora glomerata and Ulva procera. Sensitivity of the photosynthesis of (a) C. glomerata and (b) $U$. procera to $\mathrm{H}_{2} \mathrm{O}_{2}$ in NSW (natural seawater): $P-E$ curves with 0,20 and $100 \mu \mathrm{M} \mathrm{H}_{2} \mathrm{O}_{2}$ added to the NSW medium. PAR: photosynthetically active radiation

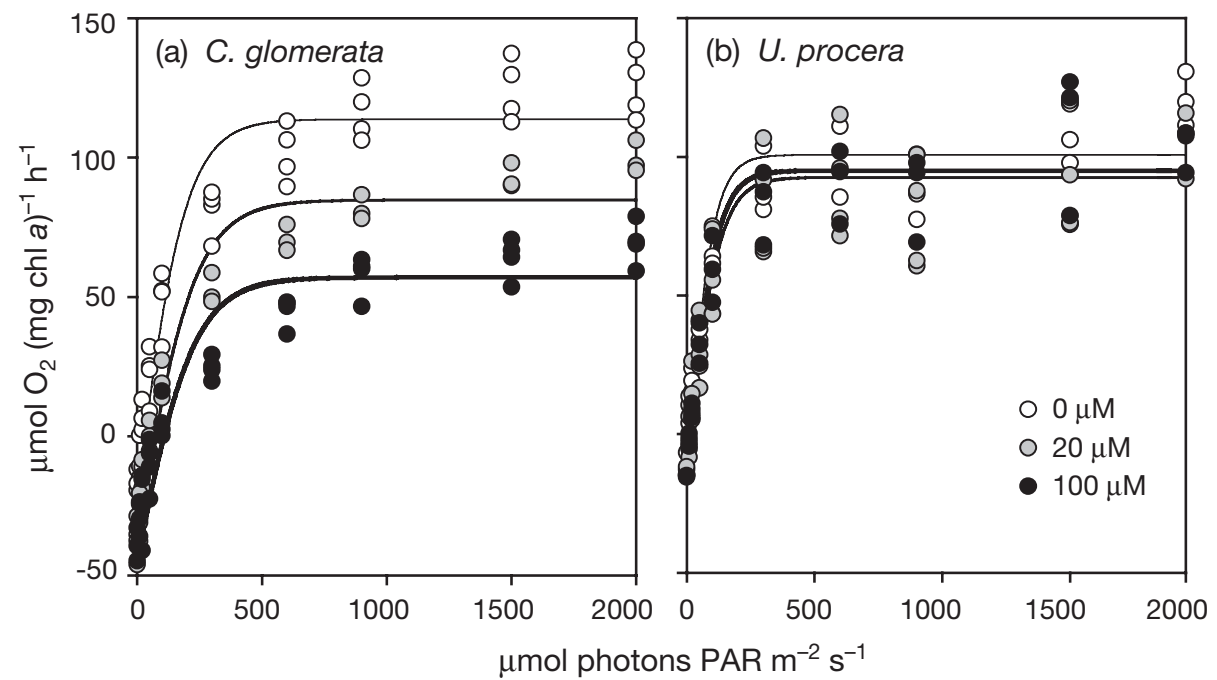




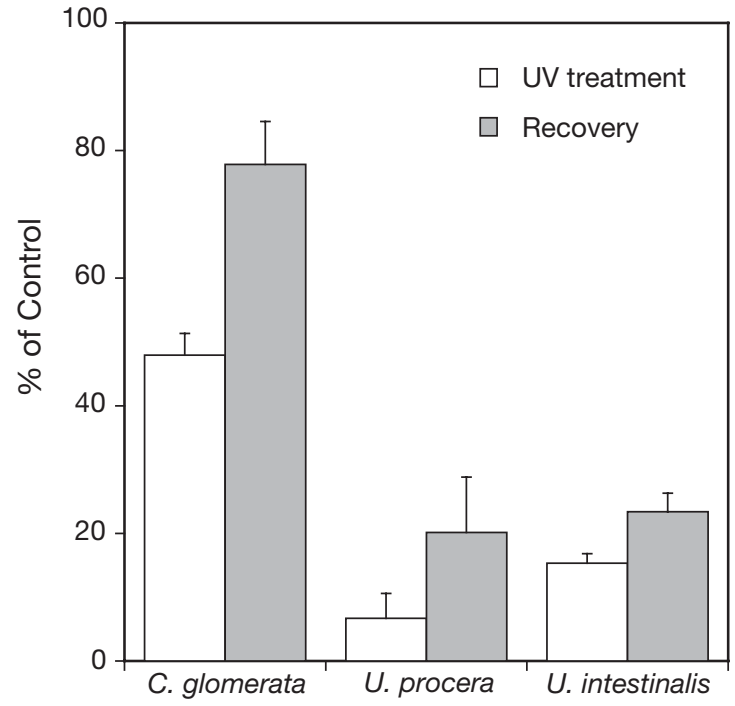

Fig. 4. The effect of UV-B radiation on the photosynthesis of Cladophora glomerata, Ulva procera and U. intestinalis expressed as $\mathrm{O}_{2}$ evolution in percent of the control. $\mathrm{O}_{2}$ evolution was measured on the same algal thalli before (control), immediately after $30 \mathrm{~min}$ of ultraviolet treatment (UV treatment) and after $10 \mathrm{~min}$ of photosynthetically active radiation after the ultraviolet treatment (recovery). Error bars show 1 standard error of the mean

\section{Sensitivity to UV-B radiation}

The photosynthesis of Cladophora glomerata, Ulva procera and Ulva intestinalis was inhibited by UV-B radiation; the strongest inhibition occurred in the 2 Ulva species (Fig. 4). The 30 min UV treatment reduced $\mathrm{O}_{2}$ evolution by $52 \pm 6 \%$ in C. glomerata and by $93 \pm 7 \%$ in $U$. procera. The same pattern was observed in the recovery treatment during which $C$. glomerata regained its photosynthesis to $78 \pm 7 \%$ of the control, while $U$. procera only recovered to $20 \pm 9 \%$ of the control.

\section{DISCUSSION}

Species of the freshwater genus Cladophora and the marine genus Ulva are notorious opportunists (Raffaelli et al. 1998). They cause nuisance blooms in lakes and shallow marine areas when general conditions for algal growth become favourable, e.g. by increased nutrient availability (Kamer et al. 2001, Gordillo et al. 2003) or increased water temperature (Snoeijs \& Prentice 1989). In a wide ecological sense, these shortlived, fast-growing easy colonisers are classified as r-strategists. Our study deals with a subdivision within this group of r-strategists into persistent and ephemeral species, with emphasis on ecophysiological aspects. In the brackish Baltic Sea, 1 Cladophora and 1 Ulva species meet and coexist in a conspicuous belt on rocky coasts. Even a simple comparison of the variability of photosynthetic rates measured on different days (Table 2, Figs. 2 \& 3) identifies C. glomerata as the more stable species compared with $U$. procera. In the highly dynamic hydrolittoral zone of the northern Baltic Sea, C. glomerata usually persists throughout the summer, while $U$. procera appears to arrive with favourable and leave with unfavourable conditions. When conditions are favourable, U. procera seems to be able to successfully compete with C. glomerata for nutrients and space when they coexist and both are in good vigour.

In comparison with the weight-specific photosynthetic properties of 12 red and brown macroalgal species growing at Askö and measured with the same photosynthetic equipment as used in the present study (Johansson \& Snoeijs 2002), the $\alpha$ and $P_{\max }$ values of Ulva procera were the highest measured. The $\alpha$ and $\mathrm{P}_{\max }$ values of the red algae Ceramium tenuicorne (Kütz.) Wærn, Ceramium nodulosum (Lightf.) Ducluz, Polysiphonia fucoides (Huds.) Grev. and the brown algae Dictyosiphon foeniculaceus (Huds.) Grev. and Pilayella littoralis (L.) Kjellm. were all higher than those of Cladophora glomerata. These observations indicate that the differences in photosynthesis between $U$. procera and C. glomerata are not caused by morphology because the 3 above-mentioned red algae all have a coarser filamentous thallus structure than C. glomerata. The relatively low photosynthetic capacity of C. glomerata (for a thin-filamentous species in the area) could not be explained by detrimental conditions either, as the algal belt was well-developed at the sampling site. Neither could it be caused by nutrient limitation because the tissue $\mathrm{C}, \mathrm{N}$ and $\mathrm{P}$ levels of C. glomerata were well balanced (Table 1), while those of $U$. procera indicated P-limitation (Björnsäter \& Wheeler 1990, Lohman \& Priscu 1992, Planas et al. 1996, Altamirano et al. 2000). A factor that partly explains the difference in photosynthetic capacity between the 2 species is the much higher chlorophyll level per unit DW in U. procera. A plausible functional explanation is that $C$. glomerata is adapted to keep its photosynthesis at a stable high (but not too high) level to be able to maintain its thallus also when carbon and other nutrients are less readily available in the dense belts. Thus, the ephemeral life form of $U$. procera may be partly driven by a lower capability of nutrient storage compared with C. glomerata.

Figueroa et al. (2003) compared photosynthetic properties and pigment composition of 2 morphologically similar Ulva species, the subtidal $U$. rotundata Bliding (shade adapted) and the intertidal $U$. olivascens P. A. Dangeard (sun adapted). The sun-adapted species showed lower pigment contents, lower $\alpha$, higher $\mathrm{P}_{\max }$ (all weight specific) and higher $E_{\mathrm{c}}$ and $E_{\mathrm{k}}$. Lower $\alpha$ 
values in combination with higher $\mathrm{P}_{\max }, E_{\mathrm{c}}$ and $E_{\mathrm{k}}$ were also typically found for the intertidal red alga Porphyra umbilicalis (L.) J. Ag. compared with the deepgrowing red alga Phycodrys rubens (L.) Batters, which has a similar morphology (Johansson \& Snoeijs 2002). Another parameter that can be used to distinguish sunand shade-adapted green algae is the ratio $\mathrm{chl} b / \mathrm{chl} a$, which is lower in sun-adapted algae (Lüning 1990, p. 307). In our case, Cladophora glomerata had lower pigment contents per unit weight, lower chl $b / \mathrm{chl} a_{\text {, }}$ lower $\alpha$ and higher $E_{\mathrm{c}}$ but also lower $\mathrm{P}_{\max }$, while $E_{\mathrm{k}}$ did not differ between the 2 species. From these measurements it can be concluded that $C$. glomerata has more features in common with sun-adapted algae, and $U$. procera, with shade-adapted algae. The main difference between $U$. procera and 'real' shade-adapted algae is its high $\mathrm{P}_{\max }$, which is a major feature of its ephemeral life form, while a lower $\mathrm{P}_{\max }$ fits the more persistent C. glomerata. In the field, neither of the 2 species was observed to be typically growing in the understorey of the other. However, its higher sensitivity to light may provide $U$. procera with the ability to invade already dense algal belts by fragments or spores, or to persist as fragments in the understorey where light penetration is limited. In this way $U$. procera would be able to easily re-establish when conditions become favourable again. The low $E_{\mathrm{c}}$ of $U$. procera (15) is comparable to that of deep-growing marine red algae such as Dilsea carnosa (Schmidel) Kuntze and Phycodrys rubens (L.) Batters, which, in the Skagerrak, have mean depth distributions of 13 and $17 \mathrm{~m}$, respectively (Johansson \& Snoeijs 2002). The $E_{\mathrm{c}}$ of $C$. glomerata (50) was high compared to the values of the other 12 previously studied species from Askö, most of which had an $E_{\mathrm{c}}$ of around 25 (Johansson \& Snoeijs 2002).

Our pH-drift experiments showed that both Cladophora glomerata and Ulva procera possess highly efficient carbon-uptake systems, active up to $\mathrm{pH} \sim 10.4$ when carbon occurred as $\mathrm{HCO}_{3}{ }^{-}(\sim 10 \%)$ and $\mathrm{CO}_{3}{ }^{2-}$ $(\sim 90 \%)$ in the brackish Baltic Sea water. Three carbonuptake mechanisms were identified by specific inhibitors in both species: an AZ-sensitive periplasmic CA, a VAN-sensitive proton pump and a DIDS-sensitive AE. In our previous studies of carbon-uptake mechanisms in marine and brackish-water algae, we measured alkalinity during $\mathrm{pH}$-drift as well, which made it possible to calculate the carbon uptake from changes in $\mathrm{pH}$ and alkalinity at a specific temperature and salinity (Choo et al. 2002, Snoeijs et al. 2002, Ray et al. 2003). In such calculations it is also necessary to correct for the buffer capacity of the inhibitors AZ and VAN in seawater of a given salinity. However, in the present comparison of the strategies of the 2 species we only wished to know which mechanisms of carbon uptake were available to C. glomerata and U. procera from the sampling site and to obtain a rough measure of the relative magnitudes of the inhibitor effects.

Algae which cannot raise the $\mathrm{pH}$ above 9 in a closed system are considered incapable of $\mathrm{HCO}_{3}{ }^{-}$membrane transport (Maberly 1990). Cladophora glomerata possesses several options for $\mathrm{HCO}_{3}{ }^{-}$transport because during photosynthesis and carbon uptake the $\mathrm{pH}$ could be raised far above 9 when $\mathrm{CA}, \mathrm{AE}$, or a proton pump were blocked. This includes uptake of $\mathrm{HCO}_{3}{ }^{-}$because inhibition of the enzyme necessary for the conversion of $\mathrm{HCO}_{3}^{-}$to $\mathrm{CO}_{2}$ (CA) still resulted in high carbon uptake rates. When $\mathrm{CA}, \mathrm{AE}$ and a proton pump were blocked simultaneously, no $\mathrm{HCO}_{3}{ }^{-}$was transported. In similar experiments with combinations of inhibitors it was found that C. glomerata could not raise the $\mathrm{pH}$ above 9 by periplasmic CA alone (DIDS + VAN treatment) or by $\mathrm{AE}$ alone (AZ + VAN treatment), but that $\mathrm{HCO}_{3}{ }^{-}$could be transported when a proton pump was active (AZ + DIDS treatment) (Choo 2001). In Ulva procera, $\mathrm{HCO}_{3}^{-}$utilisation was highly dependent on periplasmic $\mathrm{CA}_{\text {; }}$ when this enzyme was blocked, $\mathrm{AE}$ and the proton pump could not compensate for the loss in carbon uptake. The only possibility for $U$. procera to utilise $\mathrm{HCO}_{3}^{-}$( $\mathrm{pH}$ raise above 9) was when both $\mathrm{CA}$ and $\mathrm{AE}$ were available to the alga (VAN treatment). When both CA and the proton pump (DIDS treatment) were available, $\mathrm{HCO}_{3}^{-}$still could not be utilised by $U$. procera (no $\mathrm{pH}$ raise above 9 ). These results suggest that a proton pump is involved in $\mathrm{HCO}_{3}{ }^{-}$transport in C. glomerata, while in $U$. procera a proton pump transporting only $\mathrm{CO}_{2}$ seemed to be present. Thus, for $\mathrm{HCO}_{3}{ }^{-}$transport, $U$. procera appears to be solely dependent on its $\mathrm{AE}$, as previously shown for U. intestinalis by Larsson et al. (1997). C. glomerata possesses several possible mechanisms and has therefore a more flexible carbon uptake. As C. glomerata relies more on its proton pump than $U$. procera and because $\mathrm{CO}_{2}$ can be transported over all the cell membranes in $U$. procera for direct use in rubisco $\left(\mathrm{HCO}_{3}{ }^{-}\right.$ has to be converted to $\mathrm{CO}_{2}$ by intracellular $\mathrm{CA}$ ), it is probable that the carbon-uptake system of C. glomerata requires more energy. However, our results also suggest that $C$. glomerata has a carbon-uptake system which is better adapted for persistence in dense algal belts with high $\mathrm{pH}$ and carbon limitation than that of $U$. procera. Carbon limitation, and limitation of other nutrients ( $\mathrm{P}$ ?), during fast growth of $U$. procera may be the reason for its often observed sudden disappearance from the upper littoral.

While Cladophora glomerata can cope better with high light stress in the upper littoral zone, the more low-light-adapted Ulva procera removes excessive absorbed energy by the water-water cycle (Asada 1999) and produces high amounts of $\mathrm{H}_{2} \mathrm{O}_{2}$. This $\mathrm{H}_{2} \mathrm{O}_{2}$ 
is removed through diffusion out of the cells into the seawater. We showed that $\mathrm{H}_{2} \mathrm{O}_{2}$ in the seawater medium was harmful to the photosynthesis of C. glomerata, but not to that of $U$. procera. This suggests that $\mathrm{H}_{2} \mathrm{O}_{2}$ may be involved in direct competition between $U$. procera and C. glomerata as an allelochemical because $U$. procera releases much higher levels of $\mathrm{H}_{2} \mathrm{O}_{2}$ to the seawater medium than C. glomerata at high irradiation and carbon deficiency (Abrahamsson et al. 2003, Choo et al. 2004). High release of $\mathrm{H}_{2} \mathrm{O}_{2}$ may, together with intercalary growth (Table 4 ) and an ephemeral life form, prevent the growth of epiphytes. In the Baltic Sea, $U$. procera usually has conspicuously fewer epiphytes (mainly diatoms) than C. glomerata (Snoeijs 1999). Collén \& Pedersén (1996) studied the toxicity of $\mathrm{H}_{2} \mathrm{O}_{2}$ on $U$. rigida and found that photosynthesis and carbon uptake were inhibited at a concentration of $1000 \mu \mathrm{M} \mathrm{H}_{2} \mathrm{O}_{2}$ in seawater, but not at $100 \mu \mathrm{M}$. However, the unicellular green alga Euglena gracilis decreased in growth by 5 to $45 \%$ at $100 \mu \mathrm{M}$ $\mathrm{H}_{2} \mathrm{O}_{2}$ (Radtke et al. 1992). U. rigida is a close relative of $U$. procera and also releases high amounts of $\mathrm{H}_{2} \mathrm{O}_{2}$ during stress conditions. It seems logical that these species have no or very low sensitivity to $\mathrm{H}_{2} \mathrm{O}_{2}$ in the seawater, while other species, such as $C$. glomerata, are more sensitive. If $\mathrm{H}_{2} \mathrm{O}_{2}$ indeed functions as an allelochemical, as suggested by our results, it is a cheap investment for Ulva species because $\mathrm{H}_{2} \mathrm{O}_{2}$ is also a cellular waste product, and lowers the costs of intracellular defence against oxidative stress (enzymes such as catalase and ascorbate peroxidase) because $\mathrm{H}_{2} \mathrm{O}_{2}$ just diffuses out of the cells.

Lower defence against oxidative stress might explain the higher sensitivity of Ulva procera to UV-B radiation in our study. Algal sensitivity to UV-B radiation has been suggested to be related to oxidative stress tolerance (Aguilera et al. 2002, White \& Jahnke 2002). UV-B radiation causes downregulation and damage to photosystem II (PS II), which has been shown to increase the production of harmful reactive oxygen species and the activities of antioxidant enzymes in algae (Malanga \& Puntarulo 1995, Lorenz et al. 1997). U. procera has lower activities of the antioxidant enzymes ascorbate peroxidase and catalase than Cladophora glomerata (Choo et al. 2004) and lacks the xanthophyll cycle which protects PS II from

Table 4. Cladophora glomerata and Ulva procera. Comparisons of life forms, morphology and ecophysiological traits during the highest level of algal seasonal growth in July to August. DW: dry weight; CA: periplasmic carbonic anhydrase

\begin{tabular}{|c|c|c|}
\hline & C. glomerata & U. procera \\
\hline Life form & $\begin{array}{l}\text { Annual, stays attached } \\
\text { throughout summer }\end{array}$ & $\begin{array}{l}\text { Ephemeral, can appear and disappear } \\
\text { from week to week }\end{array}$ \\
\hline \multirow[t]{2}{*}{ Thallus } & $\begin{array}{l}\text { Thin filamentous, branched, } \\
\text { larger cells apical growth }\end{array}$ & $\begin{array}{l}\text { Thin filamentous, branched, } \\
\text { smaller cells, intercalary growth }\end{array}$ \\
\hline & $\begin{array}{l}\text { High P concentration, low pigment } \\
\text { concentrations per unit DW }\end{array}$ & $\begin{array}{l}\text { Low } P \text { concentration, high pigment } \\
\text { concentrations per unit DW }\end{array}$ \\
\hline $\begin{array}{l}\text { Photosynthesis } \\
\text { and respiration } \\
\text { (normalised to DW) }\end{array}$ & $\begin{array}{l}\text { Low } P_{\max } \\
\text { Low } \alpha \\
\text { High } E_{\mathrm{c}}\end{array}$ & $\begin{array}{l}\text { High } P_{\max } \\
\text { High } \alpha \\
\text { Low } E_{\mathrm{c}}\end{array}$ \\
\hline $\begin{array}{l}\text { Photosynthesis } \\
\text { and respiration } \\
\text { (normalised to chl a) }\end{array}$ & $\begin{array}{l}\text { High } R_{\mathrm{d}} \\
\text { Low } \alpha \\
\text { High } E_{\mathrm{C}}\end{array}$ & $\begin{array}{l}\text { Low } R_{\mathrm{d}} \\
\text { High } \alpha \\
\text { Low } E_{\mathrm{C}}\end{array}$ \\
\hline Carbon uptake & $\begin{array}{c}\text { Proton pump transports } \mathrm{HCO}_{3}^{-} \\
\mathrm{HCO}_{3}^{-} \text {utilisation is not dependent on CA }\end{array}$ & $\begin{array}{l}\text { Proton pump does not transport } \mathrm{HCO}_{3}^{-} \\
\mathrm{HCO}_{3}^{-} \text {utilisation is dependent on } \mathrm{CA}\end{array}$ \\
\hline \multirow[t]{3}{*}{ Sensitivity to oxidative stress } & $\begin{array}{l}\text { Low temperature }+ \text { high irradiance } \\
\text { causes less lipid damage }\end{array}$ & $\begin{array}{l}\text { Low temperature }+ \text { high irradiance } \\
\text { causes more lipid damage }{ }^{a}\end{array}$ \\
\hline & $\begin{array}{l}\text { UV-B radiation has a weaker negative } \\
\text { effect on photosynthesis }\end{array}$ & $\begin{array}{l}\text { UV-B radiation has a stronger negative } \\
\text { effect on photosynthesis }\end{array}$ \\
\hline & $\begin{array}{l}\text { Fast recovery after } \\
\text { UV-B treatment }\end{array}$ & $\begin{array}{l}\text { Slow recovery after } \\
\text { UV-B treatment }\end{array}$ \\
\hline \multirow[t]{2}{*}{ Defences against oxidative stress } & $\begin{array}{l}\text { High carotenoids/chl a ratios } \\
\text { Active xanthophyll cycle }\end{array}$ & $\begin{array}{l}\text { Low carotenoids/chl a ratios } \\
\text { No xanthophyll cycle }\end{array}$ \\
\hline & $\begin{array}{l}\text { High intracellular activities of the enzymes } \\
\text { catalase and ascorbate peroxidase } \\
\text { Low excretion of } \mathrm{H}_{2} \mathrm{O}_{2}{ }^{\mathrm{a}}\end{array}$ & $\begin{array}{c}\text { Low intracellular activities of the enzymes } \\
\text { catalase and ascorbate peroxidase } \\
\text { High excretion of } \mathrm{H}_{2} \mathrm{O}_{2}{ }^{\mathrm{a}}\end{array}$ \\
\hline
\end{tabular}


oxidative damage (Asada 1999). Low recovery of photosynthesis in $U$. procera also shows that the damage to PS II was more severe than that in C. glomerata, where photosynthesis is quickly restored. In general, algae growing near the water surface need strong protective mechanisms against UV-B radiation, and this is considered a factor affecting the vertical distribution of macroalgae (Bischof et al. 1998, Johansson \& Snoeijs 2002, Figueroa et al. 2003). The high sensitivity of $U$. procera to UV-B (93 $\pm 7 \%$ of photosynthesis lost after the 30-min treatment) is shared by its close relative $U$. intestinalis $(85 \pm 3 \%)$. Only 5 out of 32 other algal species growing at water depths from 0.25 to $20.5 \mathrm{~m}$ that were tested by the same method lost $>85 \%$ of their photosynthesis (Johansson \& Snoeijs 2002). Among these were some deep-water species, but also the filamentous brown alga Dictyosiphon foeniculaceus. This is surprising as $U$. procera, $U$. intestinalis and $D$. foeniculaceus occur in the upper littoral of the Baltic Sea, and it is possible that low resistance to UV$B$ radiation may be related to low defence against oxidative stress and an ephemeral life form.

From our experiments we can draw some conclusions that are valid when the Cladophora-belt is at its highest state of development in the Baltic Sea during summer. While the ecophysiological traits of C. glomerata seem to be directed to persistence (efficient carbon uptake and well-developed intracellular defences against oxidative stress, such as the xanthophyll cycle, enzymes and high carotenoid/chl a ratios), those of Ulva procera seem to be more engaged with large but short-term gains (efficient photosynthesis, high sensitivity to light, high pigment concentrations per unit DW, excretion of $\mathrm{H}_{2} \mathrm{O}_{2}$ ). This correlates with their different life strategies (summarised in Table 4). Ecological processes in algal belts are complicated, as shown by Lotze et al. (2000), who found that the combined effects of a propagule bank, herbivory and nutrients best explained the population development and dominance patterns of the 2 co-occurring bloom-forming macroalgae Ulva intestinalis and Pilayella littoralis in the southern Baltic Sea and that the magnitude of these effects varied with season. Our study shows that with this variety of factors the ecophysiological traits of the constituent species should also be integrated in order to explain population development and dominance patterns in macroalgal blooms.

Acknowledgements. We thank the staff of the Askö Laboratory (Stockholm University) and Mia Bengtsson for assistance during field work. We are grateful to Erik Brammer for inspiring discussions and to 2 anonymous reviewers for valuable comments. This work was sponsored by the Stockholm Marine Research Centre (SMF).

\section{LITERATURE CITED}

Abrahamsson K, Choo KS, Pedersén M, Johansson G, Snoeijs $P$ (2003) Effects of temperature on the production of hydrogen peroxide and volatile halocarbons by brackishwater algae. Phytochemistry 64:725-734

Aguilera J, Dummermuth A, Karsten U, Schriek R, Wiencke C (2002) Enzymatic defences against photooxidative stress induced by ultraviolet radiation in Arctic marine macroalgae. Polar Biol 25:432-441

Altamirano M, Flores-Moya A, Conde F, Figueroa FL (2000) Growth, seasonality, photosynthetic pigments, and carbon and nitrogen content in relation to environmental factors: a field study of Ulva olivascens (Ulvales, Chlorophyta). Phycologia 39:50-58

Asada K (1999) The water-water cycle in chloroplasts: scavenging of active oxygens and dissipation of excess protons. Annu Rev Plant Physiol Plant Mol Biol 50: 601-639

Axelsson L, Ryberg H, Beer S (1995) Two modes of bicarbonate utilization in the marine green macroalga Ulva lactuca. Plant Cell Environ 18:439-445

Bischof K, Hanelt D, Wiencke C (1998) UV-radiation can affect depth-zonation of Antarctic macroalgae. Mar Biol 131:597-605

Bischof K, Kräbs G, Wiencke C, Hanelt D (2002) Solar ultraviolet radiation affects the activity of ribulose-1,5-bisphosphate carboxylase-oxygenase and the composition of photosynthetic and xanthophyll cycle pigments in the intertidal green alga Ulva lactuca L. Planta 215:502-509

Björk M, Haglund K, Ramazanov Z, Garcia-Reina G, Pedersén $M$ (1992) Inorganic-carbon assimilation in the green seaweed Ulva rigida C. Ag. (Chlorophyta). Planta 187: $152-156$

Björnsäter BR, Wheeler PA (1990) Effect of nitrogen and phosphorus supply on growth and tissue composition of Ulva fenestrata and Enteromorpha intestinalis, Ulvales, Chlorophyta. J Phycol 26:603-611

Choo KS (2001) Uptake of inorganic carbon by macroalgae from the Baltic Sea. Licentiate thesis, Department of Botany, Stockholm University

Choo KS, Snoeijs P, Pedersén M (2002) Uptake of inorganic carbon by Cladophora glomerata (Chlorophyta) from the Baltic Sea. J Phycol 38:493-502

Choo KS, Pedersén M, Snoeijs P (2004) Oxidative stress tolerance in the filamentous green algae Cladophora glomerata and Enteromorpha ahlneriana. J Exp Mar Biol Ecol 298:111-123

Collén J, Pedersén M (1996) Production, scavenging and toxicity of hydrogen peroxide in the green seaweed Ulva rigida. Eur J Phycol 31:265-271

Collén J, Del Rio MJ, Garcia-Reina G, Pedersén M (1995) Photosynthetic production of hydrogen peroxide by Ulva rigida C. Ag. (Chlorophyta). Planta 196:225-230

Drechsler Z, Sharkia R, Cabantchik ZI, Beer S (1993) Bicarbonate uptake in the marine macroalga Ulva sp. is inhibited by classical probes of anion exchange by red blood cells. Planta 191:34-40

Dring MJ, Wagner A, Boeskov J, Lüning K (1996) Sensitivity of intertidal and subtidal red algae to UV-A and UV-B radiation, as monitored by chlorophyll fluorescence measurements: influence of collection depth and season, and length of irradiation. Eur J Phycol 31:293-302

Figueroa FL, Nygård C, Ekelund N, Gómez I (2003) Photobiological characteristics and photosynthetic UV responses in two Ulva species (Chlorophyta) from southern Spain. J Photochem Photobiol B Biol 72:35-44 
Gilmour DJ, Kaaden R, Gimmler H (1985) Vanadate inhibition of ATPases of Dunaliella parva in vitro and in vivo. J Plant Physiol 118:111-126

Glazener JA, Orlandi EW, Harmon GL, Baker CJ (1991) An improved method for monitoring active oxygen in bacteria-treated suspension cells using luminol-dependent chemiluminescence. Physiol Mol Plant Pathol 39:123-133

Gordillo FJL, Figueroa FL, Niell FX (2003) Photon- and carbon-use efficiency in Ulva rigida at different $\mathrm{CO}_{2}$ and N levels. Planta 218:315-322

Hayden HS, Blomster J, Maggs CA, Silva PC, Stanhope MJ, Waaland JR (2003) Linnaeus was right all along: Ulva and Enteromorpha are not distinct genera. Eur J Phycol 38: $277-294$

Henley WJ (1993) Measurement and interpretation of photosynthetic light-response curves in algae in the context of photoinhibition and diel changes. J Phycol 29:729-739

Jassby AD, Platt T (1976) Mathematical formulation of the relationship between photosynthesis and light for phytoplankton. Limnol Oceanogr 21:540-547

Johansson G, Snoeijs P (2002) Macroalgal photosynthetic responses to light in relation to thallus morphology and depth zonation. Mar Ecol Prog Ser 244:63-72

Kamer K, Boyle KA, Fong P (2001) Macroalgal bloom dynamics in a highly eutrophic southern California lagoon. Estuaries 24:622-634

Larsson C, Axelsson L, Ryberg H, Beer S (1997) Photosynthetic carbon utilization by Enteromorpha intestinalis (Chlorophyta) from a Swedish rock pool. Eur J Phycol 32: 49-54

Littler MM, Littler DS (1980) The evolution of thallus form and survival strategies in benthic marine macroalgae: field and laboratory tests of a functional form model. Am Nat 116:25-44

Lohman K, Priscu JC (1992) Physiological indicators of nutrient deficiency in Cladophora (Chlorophyta) in the Clark Fork of the Columbia River, Montana. J Phycol 28: $443-448$

Lorenz M, Schubert H, Forster RM (1997) In vitro- and in vivo effects of ultraviolet-B radiation on the energy transfer in phycobilisomes. Photosynthetica 33:517-527

Lotze HK, Worm B, Sommer U (2000) Propagule banks, herbivory and nutrient supply control population development and dominance patterns in macroalgal blooms. Oikos 89:46-58

Lüning K (1990) Seaweeds-their environment, biogeography, and ecophysiology. Wiley, New York

Maberly SC (1990) Exogenous sources of inorganic carbon for

Editorial responsibility: Otto Kinne (Editor-in-Chief), Oldendorf/Luhe, Germany photosynthesis by marine macroalgae. J Phycol 26: 439-449

Malanga G, Puntarulo S (1995) Oxidative stress and antioxidant content in Chlorella vulgaris after exposure to ultraviolet-B radiation. Physiol Plant 94:672-679

Moroney JV, Husic HD, Tolbert NE (1985) Effect of carbonic anhydrase inhibitors on inorganic carbon accumulation by Chlamydomonas reinhardtii. Plant Physiol 79:177-183

Planas D, Maberly SC, Parker JE (1996) Phosphorus and nitrogen relationships of Cladophora glomerata in two lake basins of different trophic status. Freshw Biol 35: 609-622

Radtke K, Byrnes RW, Kerrigan P, Antholine WE, Petering DH (1992) Requirement for endogenous iron for cytotoxicity caused by hydrogen peroxide in Euglena gracilis. Mar Environ Res 34:339-343

Raffaelli DG, Raven J, Poole L (1998) Ecological impact of macroalgal blooms. Oceanogr Mar Biol Annu Rev 36: 97-125

Ray S, Klenell M, Choo KS, Pedersén M, Snoeijs P (2003) Carbon uptake in Chara tomentosa from brackish water. Aquat Bot 76:141-154

Snoeijs P (1992) Ecology and taxonomy of Enteromorpha species in the vicinity of the Forsmark nuclear power plant (Bothnian Sea). Acta Phytogeogr Suec 78:11-23

Snoeijs P (1999) Marine and brackish waters. Acta Phytogeogr Suec 84:187-212

Snoeijs P, Prentice IC (1989) Effects of cooling water discharge on the structure and dynamics of epilithic algal communities in the northern Baltic. Hydrobiologia 184:99-123

Snoeijs P, Klenell M, Choo KS, Comhaire I, Ray S, Pedersén M (2002) Strategies for carbon acquisition in the red marine macroalga Coccotylus truncatus from the Baltic Sea. Mar Biol 140:435-444

Stiling P (2002) Ecology - theories and applications, 4th edn. Prentice Hall, Upper Saddle River, NJ

Ursi S, Pedersén M, Plastino E, Snoeijs P (2003) Intraspecific variation of photosynthesis, respiration and photoprotective carotenoids in Gracilaria birdiae (Gracilariales: Rhodophyta). Mar Biol 142:997-1007

Weykam G, Gómez I, Wiencke C, Iken K, Klöser H (1996) Photosynthetic characteristics and $\mathrm{C}: \mathrm{N}$ ratios of macroalgae from King George Island (Antarctica). J Exp Mar Biol Ecol 204:1-22

White AL, Jahnke LS (2002) Contrasting effects of UV-A and UV-B on photosynthesis and photoprotection of betacarotene in two Dunaliella spp. Plant Cell Physiol 43: $877-884$

Submitted: August 21, 2003; Accepted: March 8, 2005

Proofs received from author(s): April 23, 2005 